\title{
Development of Forestry Species Inoculated with Trichoderma spp. Fertilized with Rock Phosphate
}

\author{
Angelita Soldan ${ }^{1}$, Luciano Farinha Watzlawick ${ }^{2}$, Renato Vasconcelos Botelho ${ }^{3}$, \\ Cacilda Márcia Duarte Rios Faria ${ }^{4}$, Aline José Maia ${ }^{4}$ \\ ${ }^{1}$ Secretaria do Meio Ambiente, Guarapuva/PR, Brasil \\ ${ }^{2}$ Laboratório Manejo Florestal, Departamento de Agronomia, Universidade Estadual do Centro-Oeste - UNICENTRO, \\ Guarapuava/PR, Brasil \\ ${ }^{3}$ Laboratório Fruticultura, Departamento de Agronomia, Universidade Estadual do Centro-Oeste - UNICENTRO, \\ Guarapuava/PR, Brasil \\ ${ }^{4}$ Laboratório de Fitopatologia, Departamento de Agronomia, Universidade Estadual do Centro-Oeste - UNICENTRO, \\ Guarapuava/PR, Brasil
}

\begin{abstract}
The study aimed to determine the effects of inoculation of Trichoderma spp. on the development and extraction of nutrients from Eugenia pyriformis Cambess. (uvaieira) and Myrcianthes punges (O.Berg.) (guabiju) subjected to fertilization with rock phosphate. The treatments used at planting were: Control; Trichonat $\mathrm{PM}^{\circledast}$; Trichoderma sp. FS1; Rock phosphate; Trichonat $\mathrm{PM}^{\circledast}+$ Rock phosphate; and Trichoderma sp. FS1 + Rock Phosphate. The following characteristics were evaluated at 540 days after planting: plant height, crown diameter, branch insertion points, biomass, and nutrient content. The uvaieiras inoculated with Trichonat $\mathrm{PM}^{\circledR}$ and Thrichoderma spp. showed higher vegetative growth and higher values of $\mathrm{N}, \mathrm{P}, \mathrm{K}, \mathrm{Ca}, \mathrm{Mg}$ and $\mathrm{S}$, respectively. For guabijuzeiros, the treatment with Trichoderma spp. presented the highest insertion point of the branches without phosphorus fertilization However, the treatments did not affect nutrient extraction. Thus, Trichoderma spp. inoculants have the potential to promote vegetative growth and nutrient extraction in plants.
\end{abstract}

Keywords: Eugenia pyriformis, Myrcianthes punges, nutrient extraction. 


\section{INTRODUCTION}

Forest species have a great source of vitamins, antioxidants, and essential oils. Thus, research in these areas has increased to meet the demand from the food, cosmetics and pharmaceutical industries (Franzon et al., 2010; Marin et al., 2008). Management of fruit plants in preservation areas or on small properties can become a practice that combines environmental conservation and generates income to small farmers. Myrtaceae is a species that can be used for restoring vegetation (Lorenzi, 2002; Pirola, 2013).

The Myrcianthes punges (O.Berg.) (popularly known in Brazil as guabijuzeiro) and the Eugenia pyriformis Cambess. (popularly known in Brazil as uvaieira) which are native trees to the Southern Region of Brazil are among the plants belonging to the Myrtaceae Family. Myrcianthes punges is a perennial forest fruit tree with slow growth and Eugenia pyriformis is also a perennial forest fruit tree, but with fast growth and early fructification. Both can be used in forest management systems for reforestation of degraded areas and ciliary recomposition (Carvalho, 2010).

Technical and scientific information regarding nutritional requirements and their reflection on the productivity and quality of uvaia and guabiju fruits are scarce. The phosphorus nutrient is of paramount importance for fruit species in general, as its deficiency is marked by a delay in plant and root growth, a delay in flowering, inhibition of lateral bud sprouting and reduced quantity of fruits; and consequently, a reduction in productivity (Araújo \& Machado, 2006).

According to Lima et al. (2011), phosphorus favors roots and seedlings to develop faster, increases resistance to cold, improves water use efficiency, promotes disease resistance in some plants and increases nutrient absorption. The use of rock phosphate in its natural form is very restricted due to its low solubility, which requires an association of this material with other sources of soluble phosphorus. To increase phosphorus solubilization in natural sources, studies have been conducted with the inoculation of phosphorus solubilizing microorganisms (Novais et al., 2007).

In this context, the use of the Trichoderma spp. Fungus is highlighted. It is a natural inhabitant of soils and highly interactive in the root and in the interior of the plants through different action mechanisms such as competition, parasitism, and antibiosis against microorganisms capable of causing disease in plants (Bedendo et al., 2011). This fungus aids in decomposing and mineralizing plant residues, as well as promoting $P$ solubilization that contributes to the availability of this nutrient to the plants, allowing greater and faster absorption (Jesus et al., 2011). With the objective of evaluating the in vitro phosphate solubilization potential, Oliveira et al. (2012) used seven isolates of Trichoderma spp. and found that all were able to solubilize calcium phosphate in the culture medium.

In addition to helping in the solubility of nutrients necessary to plants, the Trichoderma genus can promote their growth due the production of Indole-3-acetic acid (IAA) (Hoyos-Carvajal et al., 2009; Carvalho et al., 2008). Fortes et al. (2007) found that the Trichoderma isolate (E15) promoted eucalyptus micro-cut rooting (Eucalyptus sp.), showing a significant increase in the rooting percentage.

In this sense, the objective of the study was to evaluate the effect of inoculating Trichoderma spp. fungus and fertilization with rock phosphate on the initial development and nutrient extraction of Eugenia pyriformis and Myrcianthes punges plants in field conditions.

\section{MATERIAL AND METHODS}

\subsection{Obtaining seedlings}

Myrcianthes punges and Eugenia pyriformis seeds were obtained from a forest fragment in the municipality of São José das Palmeiras in the western region of the State of Paraná, Brazil, and seeded in plastic pots measuring $45 \mathrm{x} 17 \mathrm{~cm}$ and $14 \mathrm{~cm}$ in height (two seeds per pot), with MECPLANTA FSC ${ }^{\circledR}$ as substrate registered at MAP PR 0954910001-0 as an "F" class soil conditioner (composition of the product: pine bark, vermiculite, corrective acidity, mineral fertilizers) and ravine soil at the ratio of 1:1, and then kept in a greenhouse under intermittent mist. The seedlings were transferred to polyethylene bags $(10 \times 20 \mathrm{~cm})$ after 60 days with a capacity of $500 \mathrm{ml}$ of MECPLANTA FSC ${ }^{\circledR}$ substrate and then remained in the greenhouse for another 90 days. The seedlings were planted in the second half of September 2011, into previously prepared pits with $2 \times 2 \mathrm{~m}$ spacing and dimensions of $40 \times 40 \times 40 \mathrm{~cm}$. 


\subsection{Implemented products}

The commercial product Trichonat $\mathrm{PM}^{\circledR}$ (Natural Rural S.A., Araraquara-SP) was used as an inoculum source of Trichoderma spp. fungi, composed of a powder formulation at a concentration of $6 \times 10^{6}$ conidia $\mathrm{g}^{-1}$. A sample of Ficus carica L. rhizospheric soil containing Trichoderma was transferred to Petri dishes containing potato-dextrose-agar (PDA) culture medium to obtain Trichoderma spp. FS1 isolates, and the plates were subsequently incubated in a growth chamber $(\mathrm{BOD}=$ bio-oxygen demand $)$ at $25^{\circ} \mathrm{C}$ with a photoperiod of $12 \mathrm{~h}$ for 7 days. After this period, $5 \mathrm{~mm}$ diameter discs of PDA culture medium containing Trichoderma mycelium were added to glass vials containing $5 \mathrm{~g}$ of sterile parboiled rice, and the vials were placed in a BOD chamber/incubator at $25^{\circ} \mathrm{C}$ with a photoperiod of $12 \mathrm{~h}$ for 20 days.

The rock phosphate used was Arad origin, which generally has 10 to $12 \%$ of $\mathrm{P}_{2} \mathrm{O}_{5}$ soluble in citric acid and total $\mathrm{P}_{2} \mathrm{O}_{5}$ contents between 28 and $30 \%$.

\subsection{Field experiment}

The experiment was carried out in Guarapuava, south-central state of Paraná, Brazil, with geographic coordinates of $25^{\circ} 23^{\prime} 36^{\prime \prime} \mathrm{S}, 51^{\circ} 27^{\prime} 19^{\prime \prime} \mathrm{W}$ and $1,120 \mathrm{~m}$ altitude. According to Köppen, the region's climate is classified as humid subtropical Cfb with mild summers, frosty winters, and annual rainfall of 1,800-2,000 mm (data provided by the Technological Institute of Meteorological System of Paraná).

The soil is classified as Distroferric Brazilian Oxisol with a typical clayey texture (Santos et al., 2006). Chemical analyses of the $0-20 \mathrm{~cm}$ soil layer carried out beforethe experiment presented the following results: $\mathrm{pH}\left(\mathrm{CaCl}_{2}\right)=5.5 ; \mathrm{H}^{+}+\mathrm{Al}^{3+}=3.62$ $\mathrm{cmol} \mathrm{dm}^{-3} ; \mathrm{Ca}^{2+}=3.3 \mathrm{cmol} \mathrm{dm}^{-3} ; \mathrm{Mg}^{2+}=3.2 \mathrm{cmol} \mathrm{dm}^{-3}$; $\mathrm{P}($ mehlich $)=1.0 \mathrm{mg} \mathrm{dm}^{-3} ; \mathrm{K}^{+}=0.28 \mathrm{cmol} \mathrm{dm}^{-3}$; $\mathrm{S}=5.7 \mathrm{mg} \mathrm{dm}^{-3} ; \mathrm{V} \%=65 \% ; \mathrm{CEC}=10.4 \mathrm{cmolc} \mathrm{dm}^{-3}$, methodology described by Malavolta et al. (1997).

The experimental design followed randomized blocks according to a $3 \times 2$ factorial scheme (inoculants $\mathrm{x}$ phosphate fertilization) with six treatments, four replications and an experimental plot constituted by one plant. The treatments consisted of the following applications to the planting pit incorporated into the soil: T1) Control; T2) Trichonat $\mathrm{PM}^{\circledR}$ (50g/pit);
T3) Trichoderma spp. FS1 (50g/pit); T4) Rock phosphate (1kg/pit); T5) Trichonat $\mathrm{PM}^{\circledR}$ (50g/pit) + Rock phosphate (1kg/pit) and T6) Trichoderma spp. FS1 (50g/pit) + Rock phosphate ( $1 \mathrm{~kg} / \mathrm{pit})$. All pits received $5 \mathrm{~kg}$ of tanned cattle manure.

\subsection{Evaluations}

The following characteristics were evaluated at 540 days post planting in July 2013: a) plant height: a measuring tape $(\mathrm{cm})$ was used from the base of the plant stem until the end of the crown; b) canopy diameter: a measuring tape on two equidistant sides $(\mathrm{cm})$ was used, c) insertion point of the branches: a measuring tape from the base of the plant stem to the insertion point of the first branch $(\mathrm{cm})$ was used.

After the measurements, the plants were completely removed from the soil for chemical analysis. The plants were excavated and divided into roots, stems, branches, and leaves. The samples were dried at $70{ }^{\circ} \mathrm{C}$ in a forced-circulation oven with air renewal. Fresh and dry mass for all parts were evaluated with a precision digital scale. Then, the samples were ground into fine particles in an electric knife mill with a $2 \mathrm{~mm}$ sieve, and stored in a cool place at room temperature until the chemical analyses were carried out.

The macronutrients contents from the shoot and the root of the plants were determined according to the methodology described by Malavolta et al. (1997). The $\mathrm{N}$ concentrations in the dry tissues were determined by digestion using sulfuric acid and semi-micro Kjeldahl method. After the nitric-perchloric acid digestion, phosphorus $(\mathrm{P})$ was determined by molecular absorption spectrophotometry, sulfur (S) by barium sulphate turbidimetry, potassium (K) by flame photometry and calcium $(\mathrm{Ca})$ and magnesium $(\mathrm{Mg})$ nutrients by atomic absorption spectrophotometry.

The nutrient content was calculated according to the dry mass and the nutrient content in the plant (= dry mass x nutrient content) (Malavolta et al., 1997).

The results were submitted to analysis of variance and the means were compared by the Tukey test when significant at 5\% probability level using the statistical program SISVAR 5.0 (Ferreira, 2011). 


\section{RESULTS}

\subsection{Vegetative growth}

Regarding the evaluations of the Eugenia pyriformis species, there was no interaction for the variables plant height and crown diameter between the factors. However, a significant effect was observed for the inoculum factor, regardless of the phosphate fertilization. The Trichonat $\mathrm{PM}^{\circledR}$ treatment had the highest plant height and crown diameter when compared to the control, which was not statistically different from the treatment with Trichoderma spp. FS1 (Figures 1A and 1B).

There was an interaction between the factors observed for the biomass and first branch insertion point evaluations in Eugenia pyriformis (Figures 1C and D). The treatment with Trichoderma spp. provided the highest biomass, followed by the Trichonat $\mathrm{PM}^{\circledR}$ treatment, which differed from the control treatment in the absence and presence of phosphate fertilization. However, only the Trichonat $\mathrm{PM}^{\circledR}$ inoculum presented a statistical difference in the phosphate fertilization, increasing plant biomass by $36 \%$, when compared to the absence of phosphate fertilization (Figure 1C). On the other hand, the Trichoderma spp. FS1 inoculum significantly increased the insertion point of the first branches of Eugenia pyriformis in the presence of phosphate fertilization, and it was statistically different from the control treatment (Figure 1D).

\section{Guarapuava-PR, 2013.}

Regarding the vegetative growth assessments of Myrcianthes punges, no significant differences were found for the variables crown diameter, plant height and biomass. For the insertion point of the first branches variable, there was an interaction between the inoculum and fertilization factors. The Trichoderma spp. treatment increased the insertion point of the branches by $130 \%$ when compared to the control in the absence of fertilization, differing statistically from those with the presence of phosphate fertilization (Figure 2). Trichoderma spp. inocula, Guarapuava-PR, 2013.

\subsection{Nutrient extraction}

A significant interaction was found between the factors of nutrient extraction results in Eugenia pyriformis plants (Table 1). In plants fertilized with rock phosphate, the Trichoderma spp. FS1 treatment provided the highest content of N, P, K, Ca and Mg in the plants increasing by $160,150,133,210$ and $133 \%$, respectively, in relation to the control without inoculation.

However, the commercial Trichonat $\mathrm{PM}^{\circledR}$ inoculum in the absence of phosphate fertilization had higher values for most of the macronutrients, followed by
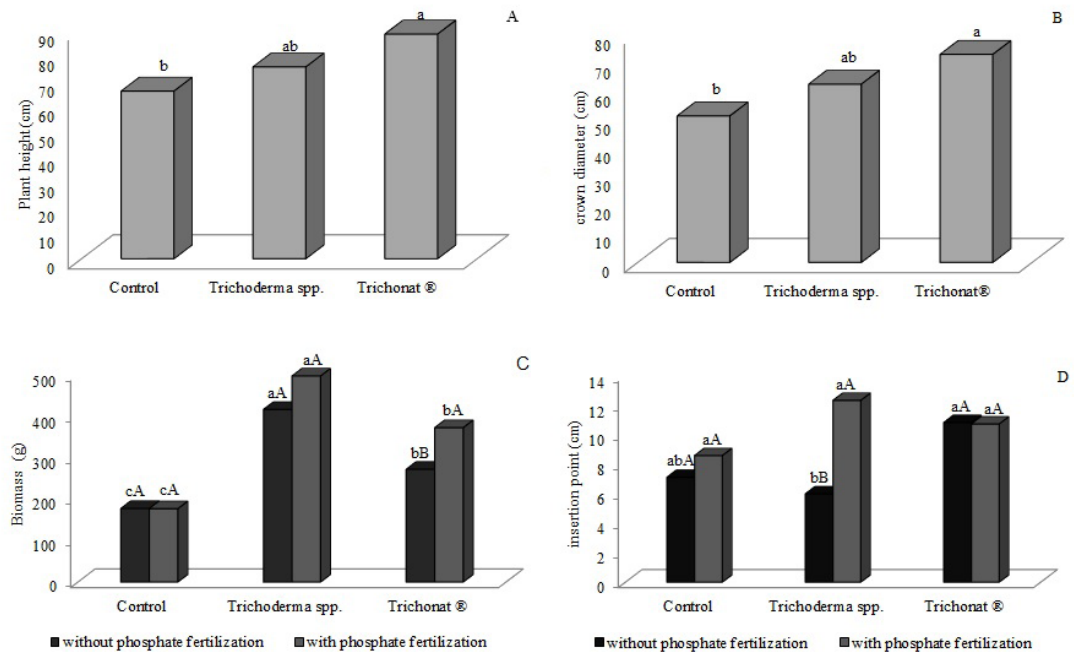

Figure 1. Plant height (A), crown diameter (B), biomass (C) and the insertion point of the first branches (D) Eugenia pyriformis subjected to several Trichoderma spp. Inocula. 


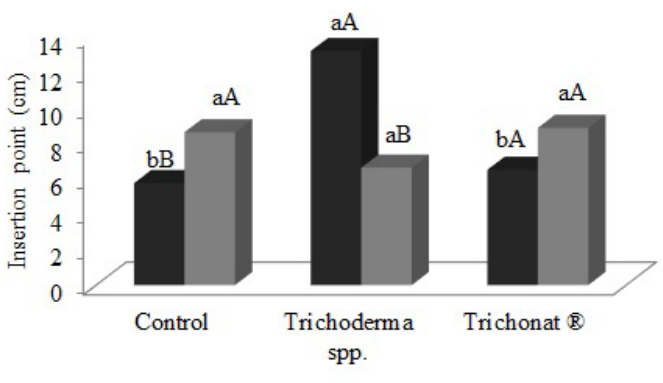

- without phosphate fertilization with phosphate fertilization

Figure 2. Insertion point of the first branch of Myrcianthes punges subjected to several.
Trichoderma spp. FS1, which differed significantly from the control treatment. For the P, K, and Mg elements, the increases were 300, 271 and 150\%, respectively, in relation to the control.

For nitrogen, the Trichoderma spp. FS1 inoculum had higher extraction. For the sulfur macronutrient, an effect was only observed for the inoculum factor, in which the maximum content was observed in the Trichonat $\mathrm{PM}^{\circledR}$ treatment (1.11 $\mathrm{g}$ of S plant $\left.{ }^{-1}\right)$, which did not significantly differ from the Trichoderma spp. FS1 treatment $\left(0.67 \mathrm{~g}\right.$ of S plant $\left.{ }^{-1}\right)$.

Table 1. Effect of different Trichoderma spp. inocula with or without phosphorus fertilization (phf) on the extraction of Eugenia pyriformis nutrients.

\begin{tabular}{|c|c|c|c|}
\hline \multirow{2}{*}{ Treatment } & \multicolumn{2}{|c|}{$\mathbf{N}\left(\right.$ g plant $\left.^{-1}\right)$} & \multirow{2}{*}{ Mean } \\
\hline & Without phf & With phf & \\
\hline Control & $1.2 \mathrm{bA}^{*}$ & $2.0 \mathrm{bA}$ & 1.6 \\
\hline Trichoderma spp.FS1 & $3.9 \mathrm{aB}$ & $5.2 \mathrm{aA}$ & 3.7 \\
\hline Trichonat PM ${ }^{\circledR}$ & $2.3 \mathrm{bA}$ & $3.2 \mathrm{bA}$ & 3.6 \\
\hline Mean & 2.5 & 3.5 & $\mathrm{CV}=22.7$ \\
\hline \multirow{2}{*}{ Treatment } & \multicolumn{2}{|c|}{ P $\left(\right.$ g plant $\left.^{-1}\right)$} & \multirow{2}{*}{ Mean } \\
\hline & Without phf & With phf & \\
\hline Control & $0.1 \mathrm{cB}$ & $0.2 \mathrm{cA}$ & 0.2 \\
\hline Trichoderma spp.FS1 & $0.2 \mathrm{bB}$ & $0.5 \mathrm{aA}$ & 0.4 \\
\hline Trichonat PM ${ }^{\circledR}$ & $0.4 \mathrm{aA}$ & $0.3 \mathrm{bA}$ & 0.4 \\
\hline Mean & 0.2 & 0.4 & $\mathrm{CV}=17.0$ \\
\hline \multirow{2}{*}{ Treatment } & \multicolumn{2}{|c|}{$\mathrm{K}\left(\right.$ g plant $\left.^{-1}\right)$} & \multirow{2}{*}{ Mean } \\
\hline & Without phf & With phf & \\
\hline Control & $0.7 \mathrm{cB}$ & $1.5 \mathrm{cA}$ & 1.1 \\
\hline Trichoderma spp.FS1 & $1.5 \mathrm{bB}$ & $3.5 \mathrm{aA}$ & 2.5 \\
\hline Trichonat PM ${ }^{\circledR}$ & $2.6 \mathrm{aA}$ & $2.7 \mathrm{bA}$ & 2.6 \\
\hline Mean & 1.6 & 2.5 & $\mathrm{CV}=13.2$ \\
\hline \multirow{2}{*}{ Treatment } & \multicolumn{2}{|c|}{$\mathrm{Ca}\left(\right.$ g plant $\left.^{-1}\right)$} & \multirow{2}{*}{ Mean } \\
\hline & Without phf & With phf & \\
\hline Control & $0.5^{\mathrm{ns}}$ & 1.0 & 0.8 \\
\hline Trichoderma spp.FS1 & 1.5 & 3.1 & 2.3 \\
\hline Trichonat PM ${ }^{\circledR}$ & 2.5 & 1.9 & 2.2 \\
\hline Mean & 1.5 & 2.0 & $\mathrm{CV}=14.0$ \\
\hline \multirow{2}{*}{ Treatment } & \multicolumn{2}{|c|}{$\operatorname{Mg}\left(g_{\text { plant }}^{-1}\right)$} & \multirow{2}{*}{ Mean } \\
\hline & Without phf & With phf & \\
\hline Control & $0.2 \mathrm{cB}$ & $0.3 \mathrm{cA}$ & 0.2 \\
\hline Trichoderma spp.FS1 & $0.3 \mathrm{bB}$ & $0.7 \mathrm{aA}$ & 0.5 \\
\hline Trichonat PM ${ }^{\circledR}$ & $0.5 \mathrm{aA}$ & $0.4 \mathrm{bB}$ & 0.5 \\
\hline Mean & 0.3 & 0.5 & $\mathrm{CV}=14.4$ \\
\hline \multirow{2}{*}{ Treatment } & \multicolumn{2}{|c|}{$S\left(\right.$ g plant $\left.^{-1}\right)$} & \multirow{2}{*}{ Mean } \\
\hline & Without phf & With phf & \\
\hline Control & $0.4^{\mathrm{ns}}$ & 0.3 & $0.4 \mathrm{~b}$ \\
\hline Trichoderma spp.FS1 & 0.5 & 0.8 & $0.7 \mathrm{ab}$ \\
\hline Trichonat PM ${ }^{\circledR}$ & 1.5 & 0.8 & $1.1 \mathrm{a}$ \\
\hline Mean & 0.8 & 0.6 & $\mathrm{CV}=69.4$ \\
\hline
\end{tabular}

${ }^{\star}$ Means followed by the same lowercase letter in the column and the same capital letter on the line do not differ from one another according to the Tukey test $(p<0.05)$. phf $=$ phosphate fertilization $\left(1 \mathrm{~kg} \mathrm{plant}^{-1}\right.$ of ARAD rock phosphate $){ }^{\text {ns }}=$ Not significant. 
Table 2. Effect of different Trichoderma spp. inocula with or without phosphorus fertilization (phf) on the extraction of Myrcianthes punges nutrients.

\begin{tabular}{|c|c|c|c|}
\hline \multicolumn{4}{|c|}{$\mathbf{N}\left(\right.$ g plant $\left.^{-1}\right)$} \\
\hline Treatment & Without phf & With phf & Mean \\
\hline Control & $3.23^{\mathrm{ns}}$ & 4.7 & 3.97 \\
\hline Trichoderma spp.FS1 & 6.12 & 3.9 & 4.99 \\
\hline Trichonat PM ${ }^{\circledR}$ & 3.4 & 3.6 & 3.49 \\
\hline Mean & 4.25 & 4.05 & $C V=49.92$ \\
\hline \multicolumn{4}{|c|}{$P\left(\right.$ g plant $\left.^{-1}\right)$} \\
\hline Treatment & Without phf & With phf & Mean \\
\hline Control & $0.28^{\mathrm{ns}}$ & 0.37 & 0.32 \\
\hline Trichoderma spp.FS1 & 0.53 & 0.31 & 0.42 \\
\hline Trichonat PM ${ }^{\circledR}$ & 0.44 & 0.27 & 0.35 \\
\hline Mean & 0.41 & 0.31 & $C V=50.40$ \\
\hline \multicolumn{4}{|c|}{$\mathrm{K}\left(\right.$ g plant $\left.^{-1}\right)$} \\
\hline Treatment & Without phf & With phf & Mean \\
\hline Control & $3.6^{\mathrm{ns}}$ & 5.8 & 4.68 \\
\hline Trichoderma spp.FS1 & 6.6 & 4.53 & 5.56 \\
\hline Trichonat PM ${ }^{\circledR}$ & 5.04 & 4.1 & 4.57 \\
\hline Mean & 5.07 & 4.8 & $\mathrm{CV}=51.32$ \\
\hline \multicolumn{4}{|c|}{$S\left(\right.$ g plant $\left.^{-1}\right)$} \\
\hline Treatment & Without phf & With phf & Mean \\
\hline Control & $0.33^{\mathrm{ns}}$ & 0.79 & 0.56 \\
\hline Trichoderma spp.FS1 & 0.54 & 0.38 & 0.46 \\
\hline Trichonat PM ${ }^{\circledR}$ & 0.38 & 0.3 & 0.34 \\
\hline Mean & 0.42 & 0.49 & $C V=81.65$ \\
\hline \multicolumn{4}{|c|}{$\mathrm{Ca}\left(\mathrm{g} \mathrm{plant}^{-1}\right)$} \\
\hline Treatment & Without phf & With phf & Mean \\
\hline Control & $4.1^{\mathrm{ns}}$ & 6.4 & 5.24 \\
\hline Trichoderma spp.FS1 & 7.3 & 5 & 6.11 \\
\hline Trichonat PM ${ }^{\circledR}$ & 5.81 & 5.3 & 5.56 \\
\hline Mean & 5.72 & 5.53 & $\mathrm{CV}=48.15$ \\
\hline \multicolumn{4}{|c|}{$\operatorname{Mg}\left(\right.$ g plant $\left.^{-1}\right)$} \\
\hline Treatment & Without phf & With phf & Mean \\
\hline Control & $0.43^{\mathrm{ns}}$ & 0.58 & 0.5 \\
\hline Trichoderma spp.FS1 & 0.74 & 0.51 & 0.63 \\
\hline Trichonat PM ${ }^{\circledR}$ & 0.72 & 0.61 & 0.66 \\
\hline Mean & 0.63 & 0.57 & $\mathrm{CV}=47.05$ \\
\hline
\end{tabular}

${ }^{n s}=$ not significant according to the Tukey probability test $(\mathrm{p}<0.05), \mathrm{phf}=$ phosphate fertilization; $\left(1 \mathrm{~kg}^{\mathrm{plant}}{ }^{-1}\right.$ of ARAD rock phosphate).

Evaluation of nutrient extraction from Myrcianthes punges plants found no significant differences for the elements $\mathrm{N}, \mathrm{P}, \mathrm{K} \mathrm{S}, \mathrm{Ca}$ and $\mathrm{Mg}$ (Table 2).

\section{DISCUSSION}

Both species showed greater vegetative development when using Trichoderma spp. as verified by increased plant height, canopy diameter, biomass or the insertion point height of the branches. Similarly, Maciel et al. (2012) also found that Eucalyptus saligna seedlings showed higher height when planted in substrate with the commercial product Trichodel ${ }^{\circledR}$ [composed of selected strains of the Trichoderma spp. fungus ( $1 \times 10^{9}$ of viable cells per $\mathrm{mL}$ )]. In sour passion fruit (Passiflora edulis var. flavicarpa Degener), effects of Trichoderma sp. inoculation (native TCN-014) have been also verified, in which larger stem length, stem diameter, true leaves, root length and total dry weight were observed two months after seedling establishment compared to 
TCC-005, the commercial strain of Trichoderma harzianum (Cubillos-Hinojosa et al., 2009).

These results indicate that the Trichoderma spp. FS1 and the Trichonat $\mathrm{PM}^{\circledR}$ directly promote plant growth through the production of hormones (auxins, cytokinins, and ethylene) or by supplying the nutrient requirements for solubilization (Machado et al., 2011; Oliveira et al., 2012). The production of Indole-3-acetic acid in eucalyptus mini-cuttings treated with Trichoderma CEN 262 isolate increased on 136\%, 136\% and 43\% of the shoot dry mass, root dry mass and mean height of the plants, respectively, compared to untreated plant cuttings (Carvalho et al., 2008),

In this study, Eugenia pyriformis plants notably showed higher nutrient extraction when inoculated with Trichoderma spp. for the elements nitrogen, phosphorus, potassium and magnesium. Similarly, Machado et al. (2011) found an increase in the mineral nitrogen absorbed by Avena strigosa Schreb (black oat) in plants inoculated with Trichoderma harzianum and nitrogen fertilization. In another study, the phosphorus content in coffee leaves was higher when submitted to Organic $\mathrm{CS}^{\circledR}$ organic soil conditioner (composed of millet colonized by the Trichoderma asperellum fungus at a concentration of $1 \times 10^{8} \mathrm{CFU} / \mathrm{g}$ ) (Jesus et al., 2011).

According to the results, a difference in the efficiency of Trichoderma sp. FS1 and Trichonat PM ${ }^{\circledR}$ was observed, which according to Ethur (2006), may be related to the ability of each isolate to produce secondary metabolites and to compete with other organisms in the rhizosphere environment of the plant.

The results show the potential of using Trichoderma sp. FS1 isolates and Trichonat $\mathrm{PM}^{\circledR}$ to promote vegetative growth in Eugenia pyriformis regardless of phosphate fertilization. Isolates of Trichoderma sp. FS1 increased biomass and nutrient content of plants in the presence of phosphate fertilizers, while Trichonat $\mathrm{PM}^{\circledR}$ provided higher nutrient extraction in non-fertilized plants.

Myrcianthes punges is a slow-growing fruit tree, and it has not been clearly benefited by localized fertilization with rock phosphate or by the inoculation of Trichoderma spp. in the first years of development. Moreover, different types of management may favor or inhibit the establishment of microbial groups in the rhizosphere (Cardoso et al., 1992). Similar results were observed by Macedo \& Teixeira (2012) when evaluating the effect of liming and phosphate fertilization on the growth of Eugenia stipitata McVaugh seedlings (popularly known as araçá-boi), finding that high doses of phosphorus in the substrate affected the nutrient availability, hindering the vegetative development of this plant.

Based on the results, Tichoderma spp. (a natural and highly interactive soil resident in the root and interior of plants) promoted vegetative growth and increased nutrient content in Eugenia pyriformis. However, it is important to continue studies for a longer period of time to better elucidate the results in Myrcianthes punges.

\section{CONCLUSION}

The best results in growth and nutrient extraction were found when using Trichonat $\mathrm{PM}^{\circledR}$ without fertilization, and Trichoderma sp. FS1 with phosphate fertilization in Eugenia pyriformis plants.

In Myrcianthes punges (O.Berg.), the Trichoderma sp. FS1 promoted a greater insertion point of the first branches However, the treatments did not influence nutrient extraction by the plants.

\section{ACKNOWLEDGEMENTS}

We thank the research bodies that collaborated with the development of the research.

\section{SUBMISSION STATUS}

Received: 5 oct., 2017

Accepted: 26 oct., 2017

\section{CORRESPONDENCE TO}
Aline José Maia
Departmento de Agronomia, Universidade Estadual do Centro Oeste, Rua Simeão Varela de Sá, 03, Vila Carli, CP 730, CEP 85040-080, Guarapuava, PR, Brasil email: alymaia2005@yahoo.com.br 


\section{FINANCIAL SUPPORT}

Coordenação de Aperfeiçoamento de pessoal de nível superior (Capes). Conselho Nacional de Desenvolvimento Científico e Tecnológico - CNPq.

\section{REFERENCES}

Araújo AP, Machado CTT. Fósforo. In: Fernandes MS, editores. Nutrição mineral de plantas. Viçosa: Sociedade Brasileira de Ciência do Solo; 2006.

Bedendo IP, Massola NS, Amorim L. Controles cultural, físico e biológico de doenças de plantas. In: Amorim L, Resende JAM, Bergamin A Fo, editores. Manual de fitopatologia. Piracicaba: Agronômica Ceres; 2011.

Cardoso EJBN, Tsai SM, Neves MCP. Microbiologia do solo. Campinas: Sociedade Brasileira de Ciência do Solo; 1992.

Carvalho MR Fo, Mello SCM, Santos RP, Menêzes JE. Avaliação de isolados de Trichoderma na promoção de crescimento, produção de ácido indolacético in vitro e colonização endofítica de mudas de eucalipto. 226. ed. Brasília: Embrapa Recursos Genéticos e Biotecnologia; 2008.

Carvalho PER. Espécies Arbóreas Brasileira. 4. ed. Colombo: Empresa Brasileira de Pesquisa e Agropecuária, Centro Nacional de Pesquisa de Florestas; 2010.

Cubillos-Hinojosa J, Valero N, Mejía L. Trichoderma harzianum como promotor del crecimiento vegetal del maracuyá (Passiflora edulis var. flavicarpa Degener). Agronomia Colombiana 2009; 27(1): 81-86.

Ethur LZ. Dinâmica populacional e ação de Trichoderma no controle de fusariose em mudas de tomateiro epepineiro [tese]. Santa Maria: Universidade Federal de Santa Maria; 2006.

Ferreira DF. SISVAR: A computer statistical analysis system. Ciência e Agrotecnologia 2011;35(6): 1039-1042. http://dx.doi.org/10.1590/S1413-70542011000600001.

Fortes FO, Silva ACF, Almança MAK, Tedesco SB. Promoção de enraizamento de microestacas de um clone de Eucalyptus sp. por Trichoderma spp. Revista Árvore 2007; 31(2): 221-228. http://dx.doi.org/10.1590/S010067622007000200004 .

Franzon RC, Gonçalves DS, Antunes CLE, Raseira BMC. Propagação vegetativa de genótipos de pitangueira (Eugenia uniflora L.) do sul do Brasil por enxertia de garfagem. Revista Brasileira de Fruticultura 2010; 32(1): 262-267. http://dx.doi.org/10.1590/S0100-29452010005000003.

Hoyos-Carvajal L, Orduz SE, Bissett J. Growth stimulation in bean (Phaseolus vulgaris L.) by Trichoderma. Biological
Control 2009; 51(3): 409-416. http://dx.doi.org/10.1016/j. biocontrol.2009.07.018.

Jesus EP, Souza CHE, Pomella AWV, Costa RL, Seixas L, Silva RB. Avaliação do potencial de Trichoderma asperellum como condicionador de substrato para a produção de mudas de café. Revista do Centro Universitário de Patos de Minas 2011; 2(2): 7-19.

Lima RLS, Severino LS, Gheyi HR, Sofiatti V, Arriel NHC. Efeito da adubação fosfatada sobre o crescimento e teor de macronutrientes de mudas de pinhão manso. Revista Ciência Agronômica 2011; 42(4): 950-956. http://dx.doi. org/10.1590/S1806-66902011000400017.

Lorenzi H. Árvores brasileiras: manual de identificação e cultivo de plantas arbóreas do Brasil. 4. ed. Nova Odessa: Instituto Plantarum; 2002.

Macedo ST, Teixeira PC. Lime and phosphorus for araza seedling formation. Acta Amazonica 2012; 42(3): 405-412.

Machado RG, Sá ELS, Damasceno RG, Hahn L, Almeida D, Moraes T et al. Promoção de crescimento de Lotus corniculatus L. e Avena strigosa Schreb pela inoculação conjunta de Trichoderma harzianum e rizóbio. Ciência e Natura 2011; 33(2): 111-126.

Maciel CG, Lazarotto M, Mezzomo R, Poletto I, Muniz MFB, Lippert DB. Control of Cylindrocladium candelabrum by Trichoderma spp. in Eucalyptus saligna seedlings. Revista Árvore 2012; 36(5): 825-832.

Malavolta E, Vitti GC, Oliveira SA. Avaliação do estado nutricional das plantas: princípios e aplicações. Piracicaba: Potafós; 1997.

Marin R, Apel MA, Limberger RP, Raseira MC, Pereira JF, Zuanazzi JA et al. Volatile components and antioxidant activity from some Myrtaceous Fruits cultivated in Southern Brazil. Latin American Journal of Pharmacy 2008; 27(2): 172-177.

Novais RF, Smyth TJ, Nunes FN. Fósforo. In: Novais RF, Alvarez VVH, Barros NF, Fontes, RLF, Cantarutti RB, Neves JCL, editores. Fertilidade do solo. Viçosa: Sociedade Brasileira Ciências do Solo; 2007.

Oliveira AG, Junior AFC, Santos GR, Miller LO, Chagas LFB. Potencial de solubilização de fosfato e produção de AIA por Trichoderma spp. Revista Verde de Agroecologia e Desenvolvimento Sustentável 2012; 7(3): 149-155.

Pirola K. Sementes de oito fruteiras nativas do bioma floresta com araucaria [dissertação]. Pato Branco: Universidade Tecnológica Federal do Paraná; 2013.

Santos HG, Jacomine PKT, Anjos LHC, Oliveira VA, Oliveira JB, Coelho MR et al. Sistema brasileiro de classificação de solos. 2. ed. Rio de Janeiro: Embrapa Solos; 2006. 306 p. 